\title{
PERLINDUNGAN KONSUMEN TERHADAP PEREDARAN, PENGGUNAAN, DAN PENGGUNAAN E-LIQUID DI DALAM ROKOK ELEKTRIK
}

\author{
Annisa Tanzil K \\ (Mahasiswi Program S1 Fakultas Hukum Universitas Tarumanagara.) \\ (E-mail: tanzilannisa@gmail.com)

\section{Dr. Ermanto Fahamsyah S.H.,M.H} \\ (Corresponding Author)
}

(Dosen Hukum Perlindungan Konsumen dan Hukum Acara PenyelesaianSengketa konsumen Fakultas Hukum Universitas Tarumanagara, Meraih SarjanaHukum dari Fakultas

Hukum Universitas Jember, Magister Hukum Ekonomi dari Universitas Indonesia dan Doktor Ilmu Hukum (Ekonomi) dari Universitas Indonesia.)

(E-mail: ermanto_fahamsyah@yahoo.co.id, ermantofahamsyah@gmail.com)

\begin{abstract}
Smoking is one activity that is still done by individuals in all ages, from teenegers to adulthood. Many ways that can be done in the effort to stop smoking, such as commited, seplacing cigarettes by consuming candy, divert cigarettes with activity, but now smokers try to quit smoking by using electric cigarettes. Which electric cigarette is one alternative that can be done as a substitute for conventional cigarettes. Electric cigarette is a set of tools that function to convert the chemicals intp steam form, and electric cigarette consists of three(3) parts, Battery(the part contains the battery), atomizer(the part that will heat and vaporize the nicotine solution), and catridge( the part contains a nicotine solution). Electric cigarette doesn't contain tobacco but using a liquid compound which concists of a mixture of water, nicotine, propylene glycol and flavors. According Badan Pengawasan Obat dan Makanan(BPOM) electric cigarette containing liquid nicotine, propylene glycol, diethyl glycol, and glycerin. If all of the materials is heated it wil produce nitrosamine compounds. And that compounds can cause cancer. Therefoe consumer protection must be strcly enforced.
\end{abstract}

Keywords: consumer, electric cigarette, electric liquid, consumer protection, danger of smoking. 


\section{PENDAHULUAN}

\section{A. Latar Belakang}

Merokok merupakan salah satu kegiatan yang masih dilakukan individu dalam segala usia mulai dari usia remaja hingga dewasa, dan tidak menutup kemungkinan untuk mereka yang sebelumnya sudah berhenti merokok, kemudian merokok kembali, ataupun bagi mereka yang sebelumnya belum pernah mencoba merokok pun menjadi tertarik untuk merokok. Ada beberapa faktor yang mempengaruhi seseorang merokok yaitu, zat nikotin yang membuat seseorang ketagihan, faktor teman, dan faktor psikologis yang merasa lebih fokus dalam mengerjakan hal atau suka memainkan asap, berdasarkan faktor-faktor tersebut diketahui bahwa berhenti merokok bukan hal yang mudah. Banyak cara yang dapat dilakukan dalam usaha berhenti merokok, seperti berkomitmen, menggantikan rokok dengan mengkonsumsi permen, mengalihkan rokok dengan beraktivitas dan menghindari rokok. Sekarang ini para perokok mencoba untuk berhenti merokok dengan menggunakan rokok elektrik, dimana rokok elektrik merupakan salah satu alternatif yang dapat dilakukan sebagai pengganti rokok.

Rokok elektrik adalah seperangkat alat yang berfungsi mengubah zat-zat kimia menjadi bentuk uap, dan rokok elektik atau e-cigarette terdiri dari 3(tiga) bagian yaitu: battery (bagian yang berisi baterai), atomizer (bagian yang akan memanaskan dan menguapkan larutan nikotin) dan catridge (berisi larutan nikotin). Rokok elektrik atau e-cigarette ini tidak mengandung tembakau melainkan dengan menggunakan senyawa cair yang terdiri dari campuran air, nikotin, propilen glikol, flavour. ${ }^{1)}$

Rokok elektrik saat ini tengah digemari, dan ada anggapan bahwa cara merokok kekinian atau vaping lebih aman dari rokok konvensional dan dapat membantu berhenti dari kebiasaan merokok, persepsi inilah membuat penggemar rokok elektrik menjamur di mana-mana. Namun, demikiankah kenyataannya?

1) Reza Kurniawan Tanuwihardja dan Agus Dwi Susanto, 2012, Rokok Elektronik (Electronic Cigarette), J Respir Indo Vol. 32, No. 1, Januari 2012, hal. 53. 
Menurut Badan Pengawasan Obat dan Makanan (BPOM), rokok elektrik mengandung nikotin cair dan bahan pelarut propilen glikol, dieter glikol, dan gliserin. Jika semua bahan itu dipanaskan akan menghasilkan senyawa nitrosamine. Senyawa tersebut dapat menyebabkan kanker. ${ }^{2)}$

Fakta hukum tentang bahaya dari E-Liquid pada rokok elektrik, telah terjadi peristiwa keracunan akibat penggunaan rokok elektrik, seorang konsumen perempuan menderita gangguan kesehatan paru-parunya, sebagaimana ceritakan oleh korbannya yaitu saudari Rhemanty, yang mempublikasikan ceritanya di salah satu media sosial bernama Path, dan dikutip oleh bogor.tribunnews.com, ${ }^{3)}$ sebagai berikut :

"Info buat temen" yg hobi ngevape..!!! tadi malam dada gw terasa ngilu..susah nafas, agak bengkak gataunya pengendapan kimia alias Liquid di paru” gue.... Disedot...Liquid Cholate semua isinya.. yg mau denger silakan enggak juga gaapa apa..!!! ngeri bgt padahal gw suka ngevape..(korbanVape) padhal ga gak minum tu liquid kenapa ngumpul semua."

Kemudian Rhemanty juga mempublikasikan ceritanya itu kedalam media sosial youtube pada tanggal 8 November 2016 dengan judul Curhat Rhemanty Korban Vape.Pasal 7 Undang-undang Nomor 8 Tahun 1999 Tentang Perlindungan Konsumen (yang selanjutnya disebut UUPK), diatur tentang kewajiban pelaku usaha. Kewajiban itu antara lain adalah menjamin mutu barang/jasa yang diproduksi dan/atau diperdagangkan berdasarkan ketentutan standar mutu barang dan/atau jasa barang yang berlaku.

Terhadap kewajiban pelaku usaha, konsumen sebagai penggguna barang atau jasa, memiliki hak atas barang atau jasa yang digunakan. Dengan kata lain perlindungan konsumen identik dengan perlidungan yang diberikann hukum tentang hak-hak konsumen. ${ }^{4)}$ Hak konsumen sebagaimana tertuang

\footnotetext{
2) Anonim, "Inilah Efek Samping Rokok Elektrik", www.meetdoctor.com, 5 april 2016.

3) Fera Nur Aini, Katanya Pakai Vape Ngga Berbahaya, Tapi Gadis Ini Malah Masuk Rumah Sakit, Jadi Pikir-Pikir Lagi Deh, www.hipwee.com. Maret 2016.

4) Celina Tri Siwi Kristiyanti, Hukum Perlindungan Konsumen,.Cetakan Keenam, (Jakarta: Sinar Grafika, 2017), hal.30.
} 
dalam pasal 4 UUPK di antaranya adalah hak atas kenyamanan dan keselamatan dalam mengkonsumsi barang dan/atau jasa.

Hak atas keamanan dan keselamatan ini dimaksudkan untuk menjamin keamanan dan keselamatan konsumen dalam penggunaan barang atau jasa yang diperolehnya, sehingga konsumen dapat terhindar dari kerugian (fisik maupun psikis) apabila mengkonsumsi suatu produk. ${ }^{5)}$ Hak konsumen ini merupakan salah satu upaya perlindungan konsumen, jadi jika suatu saat ditemukan adanya permasalahan terhadap suatu produk yang dipakai oleh konsumen, maka konsumen memiliki perlindungan hukum atas produk yang dikonsumsinya.

Ketentuan Pasal 7 UUPK menegaskan bahwa pelaku usaha dalam memperkenalkan setiap produk yang ditawarkan kepada konsumen harus disertai informasi yang benar. Informasi ini diperlukan agar konsumen tidak sampai mempunyai gambaran yang keliru atas produk barang dan jasa. Jika dikaitkan dengan hak konsumen atas keamanan, maka setiap produk yang mengandung risiko terhadap keamanan konsumen wajib disertai informasi berupa petunjuk pemakaian yang jelas. ${ }^{6)}$ Namun realitanya terhadap produk rokok elektrik dan E-Liquid tidak demikian. Hal ini dapat diketahui pada label kemasan rokok elektrik dan E-Liquid yang ternyata tidak menyertakan informasi dalam Bahasa Indonesia yang komunikatif, tetapi ditulis dalam bahasa asing. Bahkan, terdapat rokok elektrik yang tidak menyertakan label atau informasi apapun.

Pentingnya penyampaian informasi yang benar terhadap konsumen terhadap suatu produk, agar konsumen tidak salah terhadap gambaran mengenai suatu produk tertentu dan penyampaian informasi terhadap konsumen tersebut dapat berupa representasi, peringatan, maupun yang berupa instruksi. ${ }^{7)}$ Selain itu, konsumen juga sering kali kurang memahami secara jelas apa yang menjadi hak dan kewajiban mereka sebagai konsumen,

5) Ahmadi Miru \& Sutarman Yodo, Hukum Perlindungan Konsumen, Cetakan ke Sepuluh. (Jakarta: Raja Grafindo Persada, 2017), hal. 41.

6) Celina Tri Siwi Kristiyanti, Op.Cit., hal. 34.

7) Ibid., hal. 44. 
bagaimana tanggung jawab pelaku usaha serta dengan siapa konsumen tersebut berhubungan dengan hukum.

Dengan demikian, adanya fakta hukum yang menunjukkan bahaya dari E-Liquid pada rokok elektrik, disebabkan karena kurangnya informasi yang didapat oleh konsumen sebagai pengguna atau pemakai rokok elektrik tentang bagaimana cara menggunakan rokok elektrik yang benar serta tidak adanya informasi yang jelas tentang bahayanya zat-zat yang terkandungan dalam liquid/cairan pada rokok elektrik, walaupun UUPK telah mengatur tentang kewajiban pelaku usaha untuk memberikan informasi yang benar atas produk barang dan jasa. Disamping itu mudahnya konsumen memperoleh atau membeli rokok elektrik di toko-toko yang menjual rokok elektrik, maka penulis mencoba untuk menganalisa, bagaimana peran pemerintah terkait dengan pengawasan dan peredaran dari e-liquid tersebut.

\section{B. Perumusan Masalah}

Berdasarkan latar belakang yang telah dikemukakan di atas, dapat dirumuskan masalah sebagai berikut :

1. Apakah peredaran dan penggunaan e-liquid pada rokok elektrik telah diatur dalam hukum positif di Indonesia?

2. Apa bentuk pengawasan terhadap peredaran dan penggunaan e-liquid dalam rokok elektrik yang ada di Indonesia?

\section{Metode Penulisan}

1. Tipe Penelitian

Berdasarkan permasalahan yang dipilih maka tipe penelitian ini menggunakan metode penelitian hukum normatif (yuridis normative). Tipe penelitian ini dipakai untuk melakukan pertimbangan terhadap perundangundangan yang ada atau khususnya peraturan yang terkait dengan peredaran dan pengawasan e-liquid pada rokok elektrik.

2. Pendekatan Dalam Penelitian

Sesuai dengan judul yang dibuat, maka metode pendekatan yang dipakai adalah Pendekatan Perundang-Undangan (statute approach) yaitu menelaah semua Undang-Undang dan regulasi yang bersangkut paut dengan 
isu hukum yang sedang ditangani ${ }^{8}$. Pendekatan ini dimulai dengan analisa terhadap Pasal-Pasal dalam Peraturan Perundang-Undangan yang mengatur tentang masalah di atas, dikaitkan dengan fakta-fakta hukum yang di kumpulkan.

3. Sumber Penelitian.

Berkenaan dengan penelitian hukum normatif tersebut maka jenis dan sumber data yang digunakan yaitu jenis data sekunder yang dilakukan dengan studi pustaka terhadap bahan-bahan hukum dan bahan non-hukum. ${ }^{9)}$ Sedangkan, sumber data yang digunakan antara lain:

a. Bahan hukum primer adalah bahan hukum yang mempunyai sifat autoritatif, artinya mempunyai otoritas. Bahan hukum primer terdiri dari perundang-undangan. Catatan resmi atau risalah dalam pembuatan perundang-undangan yang dipakai oleh penulis dalam melakukan penelitian ini adalah Undang-Undang No.8 Tahun 1999 tentang Perlindungan Konsumen.

b. Bahan hukum sekunder adalah bahan hukum yang berupa semua publikasi tentang hukum yang bukan mer upakan dokumen-dokumen resmi, publikasi tentang hukum yang bukan merupakan dokumendokumen resmi, meliputi buku-buku teks, kamus-kamus hukum, jurnaljurnal hukum, dan komentar-komentar atas putusan pengadilan

c. Bahan Non-Hukum, yaitu bahan-bahan penunjang di luar bahan hukum primer, sekunder maupun tersier yang memberikan petunjuk tambahan terhadap bahan-bahan hukum tersebut yaitu wawancara dengan narasumber (ahli hukum) sebagai upaya mendapatkan pendapat hukum mengenai kasus yang dibahas oleh penulis.

4. Analisis Bahan Hukum

Sesuai dengan judul yang dibuat, maka metode pendekatan yang dipakai adalah Pendekatan Perundang-Undangan yaitu menelaah semua Undang-Undang dan regulasi yang bersangkut paut dengan isu hukum yang

8) Peter Mahmud Marzuki, Penelitian Hukum, Cetakan ke-6, (Jakarta: Kencana, 2010), hal. 136

9) Ibid, hal. 181-184. 
sedang ditangani atau diteliti. Pendekatan ini dimulai analisa terhadap PasalPasal dalam Peraturan Perundang-Undangan yang mengatur tentang masalah di atas, dikaitkan dengan fakta-fakta hukum yang di kumpulkan.

5. Teknik Analisis Data

Bahan hukum yang diperoleh dalam pendekatan perundangundangan (statute approach) akan diuraikan dan dihubungkan dengan permasalahan yang telah dirumuskan, dengan cara menarik kesimpulan dari suatu permasalahan yang bersifat umum terhadap permasalahan nyata $^{10}$. Selanjutnya bahan hukum yang ada diklasifikasikan sesuai dengan permasalahan penelitian, kemudian diuraikan dengan cara menganalisa fakta-fakta hukum dan disusun secara sistematis dikaitkan dengan hukum yang berlaku sehingga diperoleh jawaban yang jelas dan lengkap atas permasalahan yang diteliti.

\section{Pembahasan}

\section{A. Pengaturan Peredaran dan Penggunaan E-Liquid pada rokok elektrik dalam hukum positif di Indonesia.}

Hukum Positif Indonesia adalah sebagai 'kumpulan asas dan kaidah hukum tertulis dan tidak tertulis yang pada saat ini sedang berlaku dan mengikat secara umum atau khusus dan ditegakkan oleh atau melalui pemerintah atau pengadilan dalam Negara Indonesia ${ }^{11)}$ Merupakan suatu kenyataan bahwa betapa pun setiap kepentingan yang ada di dalam masyarakat dipertimbangkan untuk dituangkan ke dalam aturan yang bersifat umum, agar kepentingan-kepentingan itu dilindungi, maka sedemokratis apapun kehidupan bernegara dan bermasyarakat suatu bangsa, tidaklah mungkin semua aturanaturan itu, dapat mengakomodasi semua kepentingan. Dalam kehidupan nyata masalah-masalah umum yang timbul dari adanya kepentingan yang harus dilayani perlu dituangkan dalam aturan yang bersifat umum, pada masyarakat

\footnotetext{
10) Ibid. Hal. 227.

11) Bagir Manan, Op. Cit
} 
modern tempat dituangkannya perlindungan kepentingan-kepentingan tersebut adalah undang-undang ${ }^{12)}$.

Oleh karena itu, terkait dengan Pengaturan Penggunaan dan Peredaran ELiquid pada rokok elektrik dalam hukum positif di Indonesia, penulis menganalisa beberapa aturan hukum berupa Undang-Undang, Peraturan Pemerintah dan Peraturan Menteri yang mengatur tentang perlindungan Konsumen, Kesehatan, dan Zat Adiktif.

\section{Undang-undang Nomor 8 Tahun 1999 tentang Perlindungan}

\section{Konsumen}

Perlindungan konsumen adalah segala upaya yang menjamin adanya kepastian hukum untuk memberi perlindungan kepada konsumen. Kalimat yang menyatakan "segala upaya untuk menjamin adanya kepastian hukum", diharapkan sebagai benteng untuk meniadakan tindakan sewenang-wenang yang merugikan konsumen dan pelaku usaha demi untuk kepentingan perlindungan konsumen. ${ }^{13}$ Sehubungan dengan penggunaan E-Liquid yang dikonsumsi oleh konsumen, UUPK memberikan perlindungan kepada konsumen, antara lain :

a. Pasal 4, konsumen mempunyai hak atas kenyaman, keamanan, dan keselamatan dalam mengkonsumsi barang, dan hak untuk mendapatkan informasi yang benar, jelas dan jujur mengenai kondisi dan jaminan barang.

b. Pasal 7, Pelaku Usaha dalam menjalankan usahanya harus memiliki itikad baik, dengan memberi informasi yang benar, jelas dan jujur mengenai kondisi barang serta memberi penjelasan tentang penggunaannya.

c. Pasal 8, Pelaku usaha dilarang, pengertian dilarang dalam pasal ini lebih cenderung kepada kewajiban yang harus dilakukan oleh pelaku usaha, antara lain; wajib memasang label dengan menginformasikan komposisi

12) Peter Mahmud Marzuki, Pengantar Ilmu Hukum, Cetakan ke-9, (Jakarta: Kencana, 2016). Hal.136.

13) Ahmadi Miru dan Sutarman Yodo, Op, Cit. Hal.1 
yang terkandung dalam barang yang diedarkan atau diperdagangkan dan informasinya harus disampaikan dalam Bahasa Indonesia.

d. Pasal 19, Tanggung jawab pelaku usaha terhadap kerugian yang diderita oleh konsumen akibat dari mengkonsumsi barang yang diperdagangkannya.

e. Pasal 62, atas pelanggaran yang dilakukan oleh pelaku usaha sebagaimana diatur dalam pasal 8, pelaku usaha dapat dikenakan sanksi pidana.

Dari uraian pasal-pasal dalam UUPK di atas, dihubungkan dengan peredaran E-Liquid di Indonesia, Menurut analisa penulis, sebagaimana telah diatur dalam pasal 4 UUPK tersebut di atas belum dipenuhi oleh pelaku usaha.Fakta hukum belum terpenuhinya hak konsumen seperti tersebut diatas terbukti dengan adanya publikasi yang disampaikan melalui media social oleh 2(dua) orang perempuan sebagaimana telah diuraikan dalam bab sebelumnya, dimana kedua perempuan tersebut mengalami kerugiann berupa gangguan kesehatan pernafasan, jantung dan paru-paru setelah menggunakan E-Liquid.

Pelaku usaha juga terbukti tidak mempunyai itikad baik, mereka memperdagangkan E-Liquid selalu dengan promosi bahwa E-Liquid dapat membantu konsumen untuk memberhentikan kebiasaan merokok, karena E-Liquid ini bukanlah rokok, yang tidak dibuat dari tembakau atau produk olehan dari tembakau, sehingga E-Liquid jauh lebih sehat dari rokok bakar yang terbuat dari tembakau. ${ }^{14)}$ Kewajiban pelaku usaha untuk memberikan informasi yang benar terkait terhadap kandungan yang terdapat dalam $E$ Liquid, masih belum dilakukan dari hasil kunjungan ke salah satu gerai penjual E-Liquid, milik saudara Jose Sitorus (Jakarta Vape Lounge), labellabel yang menempel pada kemasan E-Liquid tersebut masih asli dari Negara pembuatnya (dari hasil wawancara bahwa semua E-Liquid yang di perdagangkan di import dari Amerika dan Cina) belum disesuaikan atau diterjemahkan ke dalam Bahasa Indonesia, maka menurut penulis informasi

14) Annisa Tanzil, Wawancara, dengan Yose Sitorus, Pelaku Usaha, Jakarta Vape Lounge, Rabu 11 April 
tentang komposisi zat-zat kimia yang terkandung dalam E-Liquid tidak terinformasi dengan benar kepada konsumen pemakainya.

Menurut Badan Pengawas Obat dan Makan, kandungan yang ada dalam cairan E-Liquid sangat berbahaya, sebagai berikut ${ }^{15)}$.

\section{a. Nikotin}

Nikotin (C10H14N2) adakah senyawa yang bersifat toksik dan sifat toksik pada nikotin sangat kuat dan kompleks, rasa mual dan muntah adalah gejala yang paling umum dari keracunan nikotin akut. Dosis yang berlebihan akan menyebabkan tremor, diikuti oleh kejang. Paralysis dan kolaps pembuluh darah adalah hal yang menonjol dari keracunan nikotin akut. Nikotin telah terbukti memiliki efek buruk pada proses reproduksi, berat badan janin dan perkembangan janin. Studi di Perancis mengevaluasi kandungan nikotin dari label E-Liquid pada rokok elektrik, dan telah dilakukan uji terhadap 20 sampel katrid, ditemukan bahwa umumnya kandungan nikotin yang sebenarnya lebih tinggi dibandingkan dengan yang tercantum di label, bahkan ditemukan beberapa kasus kndungan nikotin 2(dua) sampai 5(lima) kali lebih besar. Nikotin yang digunakan dalam jangka waktu yang lama dan gradual akan terakumulasi dalam tubuh dan mengakibatkan gangguan pada pembuluh darah, seperti penyempitan dan oengentalan darah, dan efek lainnya.

\section{b. Propylene Glycol dan Glycerol}

Propylene Glycol dan Vegetable Glycerol (biasanya disingkat PG/G). Propylene Glycol / 1,2- Propanediol (C3H8O2) adalah bahan kimia yang dapat ditemukan dalam kepulan asap buatan yang biasanya sibuat dengan "fog machine" di acara-acara panggung teatrikal, atau juga digunakan sebagai antifreeze dan zat adiktif pada makanan.Glycerol/1,2,3Propanetriol/ Glycerine/ Glyceritol/ Glycyl alcohol/ Trihydroxypropane (C3H8O2) banyak digunakan oleh industry makanan, kosmestik dan farmasi, karena memiliki banyak fungsi seperti humektan (menyerap

\footnotetext{
${ }^{15)}$ Badan POM, Kajian Rokok Elektrik Di Indonesia, Cetakan Kedua, (Jakarta: Direktorat Pengawasan Narkotika, Psikotropika, dan Zat Adiktif, 2017) Hal. 19 - 23.
} 
kelembaban) dan untuk meningkatkan kelancaran pelumasan. PG/G keduanya merupalan humektan dan emollient dalam produk kosmetik, Adapun di dalam rokok elektrik PG/G berfungsi sebagai alat angkut untuk nikotindan perisa (flavoring), serta berfungsi membuat uap semisal asap rokok. Studi tentang efek yang ditimbulkan dari asap buatan hasil pemesanan mengandung PG/G, disebutkan bahwa paparan asap buatan ini dapat berkontribusi terhadap masalah kesehatan secara akut dan kronis seperti asma, mengi (wheezimg), sesak dada, penurunan fungsi paru-paru, iritasi pernafasan, dan obstruksi jalan pernafasan. Sumber lain menyebabkan beberapa efek samping dari penggunaan Propylene Glycol adalah nyeri otot, sakit tenggorokan, dan stronger smelling urine. Semua efek ini dapat diperoleh dsri penggunaan E-Liquid pada rokok elektrik yang menggunakan Propylene Glycol.

\section{c. Kadar Perisa ( Flavoring)}

Salah satu daya tarik dari rokok elektrik adalah variasi beberapa pilihan rasa dan aroma yang tersedia, mulai dari rasa buah-buahan, mint, menthol, rokok konvensional, bahkan mothers's milk juga ada tersedia. WHO menemukan lebih dari 8000 jenis flavoring (perisa). Studi menunjukan senyawa yang aman dikonsumsi secara langsung tidaklah otomatis juga aman ketika di inhalasi, contohnya Diacetyl (butanedione or butan-2,3-dione) walaupun dinyatakan aman untuk dikonsumsi langsung sebagai flavoring dalam mentega namun ketika di inhalasi dapat berpotensi menyebabkan bronchiolitis obliteransi, penyakit hati yang sangat serius. Berdasarkan uraian kandungan di atas, dapat disimpulkan betapa berbahayanya E-Liquid bila dikonsumsi oleh konsumen manusia. Seharusnya informasi ini disampaikan secara jujur oleh pelaku usaha melalui label dalam kemasan E-Liquid, walaupun pelaku usaha mengatakan bahwa labelisasi sudah dilakukan, tetapi hal ini tetap saja tidak sesuai dengan UUPK yang mewajibkan labelisasi dalam Bahasa Indonesia. 


\section{Undang-undang Nomor 36 Tahun 2009 tentang Kesehatan.}

Pasal 1 Undang-undang Nomor 36 Tahun 2009 Tentang Kesehatan menerangkan, Kesehatan adalah keadaan sehat, baik secara fisik, mental, spritual maupun sosial yang memungkinkan setiap orang untuk hidup produktif secara sosial dan ekonomi. Dalam undang-undang ini, tidak diatur secara khusus tentang rokok dan sejenisnya seperti E-Liquid pada rokok elektrik, melainkan hanya memberikan gambaran singkat tentang zat apa saja yang dapat dikategorikan sebagai zat adiktif.

\section{Pasal 113:}

ayat (1), Pengamanan penggunaan bahan yang mengandung zat adiktif diarahkan agar tidak mengganggu dan membahayakan kesehatan perseorangan, keluarga, masyarakat, dan lingkungan.

Ayat (2) Zat adiktif sebagaimana dimaksud pada ayat (1) meliputi tembakau, produk yang mengandung tembakau, padat, cairan, dan gas yang bersifat adiktif yang penggunaannya dapat menimbulkan kerugian bagi dirinya dan/atau masyarakat sekelilingnya.

Dalam penjelasan undang-undang tentang kesehatan, tidak dijelaskan tentang apakah zat adiktif itu, walaupun dalam pasal 113 ayat (2) diterangkan zat adiktif itu meliputi tembakau, produk yang mengandung tembakau. padat, cairan, dan gas yang bersifat adiktif yang penggunaannya dapat menimbulkan kerugian bagi dirinya dan/atau masyarakat sekelilingnya. Untuk memahami apakah yang dimakasud dengan zat adiktif, undang-undang ini menjelaskan bahwa terkait dengan pengamanan bahan yang mengandung zat adiktif akan ditetapkan dengan Peraturan Pemerintah, sehingga dapat disimpulkan Undangundang kesehatan hanya memberikan gambaran saja bahwa zat adiktif berbahaya bagi penggunanya dan masyarakat sekitar dimana pengguna itu berada. 


\section{Peraturan Pemerintah Republik Indonesia Nomor 109 Tahun 2012}

\section{tentang Pengamanan Bahan yang Mengandung Zat Adiktif Berupa}

\section{Produk Tembakau Bagi Kesehatan}

Pelaksanakan ketentuan Pasal 116 Undang-Undang Nomor 36 Tahun 2009 tentang Kesehatan, Pemerintah telah menetapkan Peraturan Pemerintah tentang Pengamanan Bahan Yang Mengandung Zat Adiktif Berupa Produk Tembakau Bagi Kesehatan. Peraturan Pemerintah ini jelas merangkan, tentang definisi dari Zat Adiktif, yaitu bahan yang menyebabkan adiksi atau ketergantungan yang membahayakan kesehatan dengan ditandai perubahan perilaku, kognitif, dan fenomena fisiologis, keinginan kuat untuk mengkonsumsi bahan tersebut, kesulitan dalam mengendalikan penggunaannya, memberi prioritas pada penggunaan bahan tersebut daripada kegiatan lain, meningkatnya toleransi dan dapat menyebabkan keadaan gejala putus zat.

Undang-undang Kesehatan menjelaskan bahwa zat adiktif terkandung dalam tembakau dan produk yang mengandung tembakau, padat, cair dan gas. Tidak menjelskan produk apa yang dimaksud, tetapi dalam Peraturan Pemerintah Nomor 109 Tahun 2012 , dengan jelas diterangkan bahwa yang dimaksud produk tembakau atau produk yang mengandung tembakau dijelaskan dalam Pasal 1 yaitu ${ }^{16):}$

"Rokok adalah salah satu Produk Tembakau yang dimaksudkan untuk dibakar dan dihisap dan/atau dihirup asapnya, termasuk rokok kretek, rokok putih, cerutu atau bentuk lainnya yang dihasilkan dari tanaman nicotiana tabacum, nicotiana rustica, dan spesies lainnya atau sintetisnya yang asapnya mengandung nikotin dan tar, dengan atau tanpa bahan tambahan".

Pengertian dari produk tembakau dijelaskan dalam pasal $4^{17)}$, yaitu :

16) Indonesia, Peraturan Pemerintah Republik Indonesia Nomor 109

Tahun 2012. Peraturan Tentang Pengamanan Bahan yang Mengandung Zat Adiktif Berupa Produk Tembakau Bagi Kesehatan. (Lembaran Negara Republik Indonesia Tahun 2012 Nomor 278). Pasal 1 ayat (3)

17) Ibid., hal. 44. 
Produk Tembakau yang diatur dalam Peraturan Pemerintah ini meliputi Rokok dan Produk Tembakau lainnya yang penggunaannya terutama dengan cara dibakar dan dihisap dan/atau dihirup asapnya, yang mengandung Zat Adiktif dan bahan lainnya yang berbahaya bagi kesehatan.

Dari pasal-pasal dalam Peraturan Pemerintah di atas, dapat disimpulkan dalam sebagai berikut :

a. Rokok adalah produk tembakau, atau produk lainnya yang dihasilkan dari tanaman nicotiana tabacum nicotiana rustica, dan spesies lainnya atau sintetisnya. Tentang tanaman nicotiana tabacum, dan nicotiana rustica dalam Penjelasan Pasal 1 dari Peraturan Pemerintah ini, tidak dijelaskan secara rinci bentuk dan jenisnya penjelasannya hanya dikatakan cukup jelas, sehingga dapat disimpulkan bahwa rokok harus dihasilkan dari tanaman tembakau, dan olehan tembakau serta berasal dari tanaman nicotiana tabacum dan nicotiana rustica, dan spesies lainnya atau sintetisnya maka selain dari tanaman-tanaman tersebut tidak dapat dikategorikan sebagai rokok, tetapi ada hal yang kurang jelas di sini yaitu terkait dengan tanaman dari spesies lainnya dan bahan bahan sintetis.

b. Bentuk rokok adalah rokok kretek, rokok putih, cerutu dan bentuk lainnya.

c. Penggunaannya adalah dengan cara dibakar dan dihisap dan/atau dihirup asapnya.

Jika memperhatikan kesimpulan tersebut di atas, baik keterangan yang dijelaskan dalam Undang-undang Kesehatan dan Peraturan Pemerintah Tentang Pengamanan Bahan yang Mengandung Zat Adiktif Berupa Produk Tembakau Bagi Kesehatan, sudah cukup jelas menggambarkan bahwa zat adiktif itu terkandung dalam tanaman tembakau, produk olahan tembakau, tanaman nicotiana tabacum dan tanaman nicotiana rustica, sementara untuk tanaman spesiaes lainnya serta berasal dari bahan-bahan sintetis lainnya terlalu luas untuk diartikan dan menurut penulis, penjelasan ini perlu diklarifikasi kembali oleh Pemerinntah tentunya melalui penelitian dengan cara melakukan pengujian secara laboratorium. Menurut Ibu Amatul Syukra Tampubolon, S.Si.,Apt, selaku Kepala 
Seksi Label Produk Tembakau Direktorat Pengawasan Narkotika, Psikotropika dan Zat Adiktif Badan Pengawas Obat dan Makanan (BPOM), Sesuai Visi BPOM untuk meningkatkan kesehatan masyarakat, maka BPOM hanya akan mengevaluasi pada produk yang di daftarkan sebagai Obat, sedangkan E-Liquid sendiri bukan merupakan Obat sehingga BPOM tidak perlu melakukan kajian atau uji klinis seperti halnya Obat dan makanan, kalaupun BPOM mempublikasikan kandungan kimia yang ada saat ini dalam E-Liquid pada rokok elektrik itu bukanlah hasil kajian BPOM melainkan BPOM mengambil dari apa yang telah dilakukan oleh World Health Organisation (WHO terhadap E-Liquid yang beredar di seluruh dunia. Bagi BPOM sudah sangat jelas bahwa E-Liquid pada rokok elektrik sama bahayanya dengan rokok hasil olahan temabakau, maka BPOM pun tidak memberikan izin edar terhadap E-Liquid pada rokok eleltrik. ${ }^{18}$ Ibu Amatul Syukra Tampubolon menambahkan, bahwa BPOM mendesak Kementrian Perdagangan untuk membuat aturan terkait dengan peredaran E-Liquid pada rokok elektrik yang semakin marak, di khawatirkan pertumbuhan perokok semakin meningkat, jika peredaran E-Liquid tidak dilakukan pengawasan, karena Peraturan Pemerintah Republik Indonesia Nomor 109 Tahun 2012 Tentang Peraturan Tentang Pengamanan Bahan yang Mengandung Zat Adiktif Berupa Produk Tembakau Bagi Kesehatan tidak dapat diterapkan, Peraturan Pemerintah ini tidak mengatur tentang E-Liquid pada rokok elektrik.

Pasal 60 ayat (1) memberikan kewenangan kepada Kepala Badan, dalam hal ini adalah BPOM untuk melakukan pengawasan terhadap Produk Tembakau yang beredar, promosi, dan pencantuman peringatan kesehatan dalam iklan dan kemasan produk tembakau, menurut Ibu Syukra, pengawasan dilakukan hanya untuk kandungan nikotin dan iklan saja untuk produk rokok sementara untuk melakukan pengkajian produk E-Liquid, dan pengawasan peredarannya bukan merupakan Tugas Pokok dan Fungsi (TUPOKSI) dari BPOM. Rokok saja yang

${ }^{18}$ Annisa Tanzil, Wawancara, dengan Amatul Syukra Tampubolon, Kepala Seksi Pengawasan Produk Tembakau dan Label Direktorat NAPZA BPOM, Kamis 19 April 2018 
sudah jelas ada aturan hukumnya BPOM tidak melakukan pengawasan peredaran, apalagi E-Liquid yang belum ada aturanya. ${ }^{19}$.

Pandangan penulis, terkait dengan apa yang menjadi dasar dari BPOM untuk tidak bisa melakukan pengawasan terhadap peredaran E-Liquid cukup ironi karena disatu sisi BPOM tidak memberikan ijin edar dengan alasan produk E-Liquid sangat merugikan kesehatan manusia, disisi lainnya karena tidak sesuai dengan TUPOKSI nya, pengawasan peredaran E-Liquid bukan merupakan kewenangannya, penulis sependapat dengan Ibu Susanti Adi Nugroho selaku akademisi, dalam kesempatan wawancara dengan beliau menyampaikan bahwa, sikap BPOM sangat tidak tepat, TUPOKSI bukan menjadi alasan untuk tidak bertanggung jawab terhadap peredaran suatu barang yang dikonsumsi oleh manusia, sepanjang barang-barang yang diproduksi oleh pelaku usaha ini dikonsumsi oleh manusia dan berpengaruh kepada kesehatan konsumen yang mengkonsumsinya maka BPOM harus bertindak tegas dan tetap melakukan pengawasan peredaran untuk produk jenis apapupun.

4. Peraturan Kementrian Perdagangan Nomor 86 Tahun 2017 tentang Ketentuan Impor Rokok Elektrik.

Pasal 1 dari Peraturan Kementrian Perdagangan ini, menjelaskan tentang E-Liquid dalam rokok elektrik, sebagai berikut ${ }^{20)}$, yaitu:

Rokok Elektrik adalah perangkat rokok yang digunakan dengan memanaskan cairan yang menghasilkan asap dan dihisap oleh pemakainya yang termasuk likuid nikotin dan pengganti likuid nikotin yang digunakan sebagai isi mesin dan paratus elektrik.

${ }^{19}$ Ibid.

20) Indonesia, Peraturan Menteri Perdagangan Nomor 86 Tahun 2017, Tentang Tata Cara Impor Rokok Elektrik, (Berita Negara Nomor No.1591, 2017). Pasal 1. 
Bunyi pasal 1 tersebut, tidak menggambarkan secara rinci tentang likuid nikotin itu sendiri, apasaja unsur kimia yang dapat dikategorikan sebagai likuid nikotin, hal ini penting untuk diketahui. Agar komposisi yang ada dalam $E$ Liquid yang beredar saat ini dapat dikategorikan sesuai dengan Peraturan Kementrian Perdagangan ini.

Peraturan Kementrian Perdagangan Nomor 86 Tahun 2017, berisi 24 (duapuluh empat) pasal, dan semua pasal-pasalnya mengatur persyaratan administtrasi dan persyaratan teknis yang harus dipenuhi oleh pelaku usaha dalam melakukan kegiatan Impor Rokok Elektrik beserta alat-alat pendukungnya ke Indonesia, dari 24(duapuluh empat) pasal tersebut, tidak ada satu pasalpun yang menjelaskan tentang pengawasan terhadap peredaran dari Rokok Elektrik itu sendiri, padahal BPOM sangat berharap bahwa Kementrian Perdagangan dapat menerbitkan aturan hukum terkait dengan pengawasan dari peredaran E-Liquid, yang sampai saat ini semakin bertumbuh pesat dan memberikan sumbangan yang sangat berarti terhadap peningkatan jumlah perokok di Indonesia.

\section{Peraturan Menteri Keuangan Nomor 146/PMK.010/2017 tentang Tarif Cukai Hasil Tembakau.}

Peraturan Menterri Keuangan ini, tidak mengatur tentang pengawasan dan peredaran dari E-Liquid, dalam peraturan Menteri Keuangan ini, E-Liquid dikategorikan sebagai hasil olahan tembakau, padahal menurut pelaku usaha $E$ Liquid bukan merupakan hasil olahan tembakau dan BPOM pun menegaskan bahwa, perlu ada kajian dengan menguji E-Liquid di Laboratorium agar jelas tentang komposisi E-Liquid, jadi Kementrian keuangan memaksakan E-Liquid sebagai produk dari hasil Pengolahan Tembakau Lainnya, walaupun hasil pengujian untuk itu belum pernah dilakukan oleh instansi manapun termasuk BPOM.

Pasal 19 dari peraturan ini menjelaskan bahwa HPTL adalah Hasil Pengolahan Tembakau Lainnya yang meliputi :

a. ekstrak dan esens tembakau;

b. tembakau molasses; 
c. tembakau hirup (snuff tobacco); atau

d. tembakau kunyah (chewing tobacco)

Terhadap Hasil Pengolahan Tembakau Lainnya, Peraturan ini membebani cukai sebesar $57 \%$ sebagaimana diatur dalam Pasal 6 ayat (3) dari peraturan ini. Dan aturan ini akan diberlakukan tehitung tanggal 1 Juli 2018. Pertanyaannya adalah, apakah Kementrian Keuangan sudah berkordinasi dengan BPOM tentang kategori E-Liquid jika dimasukkan sebaggai hasil olahan tembakau, karena menurut BPOM, Peraturan Pemerintah Republik Indonesia Nomor 109 Tahun 2012 Tentang Peraturan Tentang Pengamanan Bahan yang Mengandung Zat Adiktif Berupa Produk Tembakau Bagi Kesehatan tidak bisa diterapkan untuk mengatur E-Liquid, karena E-Liquid perlu dilakukan penguujian secara laboratorium untuk membuktikan bahwa terdapat kandungan hasil olahan tembakau, dan sampai saat ini uji laboratorium tersebut belum pernah dilakukan karena menurut BPOM pengujian tersebut secara TUPOKSI bukan menjadi kewenangan BPOM.

Menurut pandangan penulis, jika kategori tembakau dan hasil olahan tembakau tidak dapat diterapkan dalam Peraturan Pemerintah Nomor 109 Tahun 2012, maka pembebanan cukai tehadap E-Liquid yang diterapkan dalam Peraturan Menteri Keuangan sebagai Hasil Pengolahan Tembakau Lainnya belum tepat.

B. Bentuk Pengawasan Terhadap Peredaran dan Penggunaan E-Liquid dalam Rokok Elektrik yang ada di Indonesia.

Pasal $30 \mathrm{UUPK}^{21)}$, menjelaskan :

1. Pengawasan terhadap penyelenggaraan perlindungan konsumen serta penerapan ketentuan peraturan perundang-undangannya diselenggarakan oleh pemerintah, masyarakat, dan lembaga perlindungan konsumen swadaya masyarakat.

2. Pengawasan oleh pemerintah sebagaimana dimaksud pada ayat (1) dilaksanakan oleh Menteri dan/atau menteri teknis terkait.

21) Ibid., hal. 44. 
3. Pengawasan oleh masyarakat dan lembaga perlindungan konsumen swadaya masyarakat dilakukan terhadap barang dan/atau jasa yang beredar di pasar.

4. Apabila hasil pengawasan sebagaimana dimaksud pada ayat (3) ternyata menyimpang dari peraturan perundang-undangan yang berlaku dan membahayakan konsumen, Menteri dan/atau menteri teknis mengambil tindakan sesuai dengan peraturan perundang-undangan yang berlaku.

5. Hasil pengawasan yang diselenggarakan masyarakat dan lembaga perlindungan konsumen swadaya masyarakat dapat disebarluaskan kepada masyarakat dan dapat disampaikan kepada Menteri dan Menteri teknis.

6. Ketentuan pelaksanaan tugas pengawasan sebagaimana dimaksud pada ayat (1), ayat (2), dan ayat (3) ditetapkan dengan Peraturan Pemerintah.

Apabila diperhatikan substansi dari pasal 30 tersebut, bahwa pengawasan lebih banyak menitik beratkan kepada peran masyarakat dan Lembaga Perlindungan Konsumen Swadaya Masyarakat, dibanding dengan Pemerintah yang pelaksanaanya dilakukan oleh Menteri dan /atau Menteri Teknis yang terkait, ayat 4 dari pasal tersebut juga menentukan bahwa, apabila pengawasan oleh masyarakat dan Lembaga Perlindungan Konsumen Swadaya Masyarakat terdapat hal-hal yang menyimpang dari peraturan perundang-undangan yang berlaku dan membahayakan konsumen, Menteri dan /atau Menteri Teknis yang terkait mengambil tindakan sesuai dengan peraturan perundang-undangan yang berlaku ${ }^{22)}$.

Bentuk pengawasan yang diatur dalam Undang-undang Nomor 36 Tahun 2009 tentang Kesehatan. Sebagai berikut :

Pasal $182^{23)}$.

(1) Menteri melakukan pengawasan terhadap masyarakat dan setiap penyelenggara kegiatan yang berhubungan dengan sumber daya di bidang kesehatan dan upaya kesehatan.

22) Ahmadi Miru dan Sutarman Yodo, Op. Cit. Hal. 189

${ }^{23}$ Indonesia, Undang-Undang Nomor 36 Tahun 2009 Tentang Kesehatan, Pasal 182 
(2) Menteri dalam melakukan pengawasan dapat memberikan izin terhadap setiap penyelenggaraan upaya kesehatan.

(3) Menteri dalam melaksanakan pengawasan sebagaimana dimaksud pada ayat (1) dan ayat (2) dapat mendelegasikan kepada lembaga pemerintah non kementerian, kepala dinas di provinsi,dan kabupaten/kota yang tugas pokok dan fungsinya di bidang kesehatan.

(4) Menteri dalam melaksanakan pengawasan mengikutsertakan masyarakat.

Menteri yang dimaksud dalam pasal di atas adalah Menteri Kesehatan, pengawasan yang dilakukan adalah terhadap sumber daya manusia yang membidangi masalh-masalah kesehatan seperti dokter, bidan, perawat dan sebagainya dalam tanggung jawab mereka melakukan kegiatan yang dilakukan secara terpadu, terintegrasi dan berkesinambungan untuk memelihara dan meningkatkan derajat kesehatan masyarakat dalam bentuk pencegahan penyakit, peningkatan kesehatan, pengobatan penyakit, dan pemulihan kesehatan. Untuk pelaksanaan pengawasan Menteri dapat mendelegasikan tugasnya kepada Lembaga Pemerintah non Kementrian (BPOM), juga kepada kepala dinas kesehatan di Provinsi maupun di Kabupaten.

Bentuk pengawasan yang dilakukan menurut Peraturan Pemerintah Republik Indonesia Nomor 109 Tahun 2012. Peraturan Tentang Pengamanan Bahan yang Mengandung Zat Adiktif Berupa Produk Tembakau Bagi Kesehatan, diatur dalam :

$$
\text { Pasal 5924): }
$$

(1) Menteri, menteri terkait, Kepala Badan, dan Pemerintah Daerah melakukan pengawasan atas pelaksanaan upaya pengamanan bahan yang mengandung Zat Adiktif berupa Produk Tembakau bagi kesehatan sesuai dengan tugas dan fungsi masing-masing

24) Indonesia, Peraturan Pemerintah Republik Indonesia Nomor 109 Tahun 2012. Peraturan Tentang Pengamanan Bahan yang Mengandung Zat Adiktif Berupa Produk Tembakau Bagi Kesehatan. (Lembaran Negara Republik Indonesia Tahun 2012 Nomor 278). Pasal 59 
Dalam pasal 59 Peraturan Pemerintah Nomor 109 Tahun 2012, Pemerintah bersama-sama dengan Kementrian terkait, BPOM, dan Pemerintah Daerah mengawasi peredaran zat adiktif dari produk-produk hasil olahan tembakau yang beredar, sesuai dengan peran mereka masing masing.

Pasal 60 25 ):

Pengawasan terhadap Produk Tembakau yang beredar, promosi, dan pencantuman peringatan kesehatan dalam iklan dan Kemasan Produk Tembakau dilaksanakan oleh Kepala Badan.

Pasal 60 di atas, Pemerintah mengamanatkan kepada Kepala BPOM untuk melakukan pengawasan terhadap produk-produk tembakau terkait dengan peredarannya, apakah sudah sesuai dengan kewajiban-kewajiban yang harus dipatuhi oleh pelaku usaha sesuai Peraturan Pemerintah nommor 109 Tahun 2012, tentang kewajiban pencantuman peringatan kesehatan dalam kemasan,dan cara melakukan iklan untuk produk-produk tembakau yang dibuat oleh pelaku usaha. Dengan demikian dapat disimpulkan bahwa bentuk pengawasan yang berlaku sekarang ini adalah pengawasan terhadap produkproduk tembakau dan olahan tembakau, bagaimana dengan pengawasan untuk E-Liquid. Sebagaimana telah di uraikan dalam perumusan masalah sebelumnya, bahwa E-Liquid tidak bisa dimasukkan kedalam kategori produk hasil olahan tembakau, perlu ada kajian secara laboratorium untuk dapat mengkategorikan E-Liquid sebagai bagian dari produk berbahan dasar tembakau atau olahan tembakau. BPOM sendiri menjelaskan bahwa sampai saat ini kajian terhadap komposisi yang terkandung di dalam E-Liquid belum dilakukan sehingga aturan hukum yang mengatur tentang peredaran zat adiktif hanya berlaku untuk produk-produk hasiil olahan tembakau dan tanaman lainnya sesuai Peraturan Pemerintah nomor 109 Tahun 2009.

Kesimpulan akhirnya adalah, karena aturan hukum tentang pengawasan dan peredaran E-Liquid belum di atur dalam hukum positif Indonesia maka

25) Indonesia, Peraturan Pemerintah Republik Indonesia Nomor 109 Tahun 2012. Tentang Pengamanan Bahan yang Mengandung Zat Adiktif Berupa Produk Tembakau Bagi Kesehatan. (Lembaran Negara Republik Indonesia Tahun 2012 Nomor 278). Pasal 60 
bentuk pengawasan terhadap peredaran dan penggunaan E-Liquid dalam Rokok Elektrik yang ada di Indonesia juga belum ada.

\section{Penutup}

A. Kesimpulan Terhadap Pengaturan Perdaran dan Penggunaan $E$ Liquid pada Rokok Elektrik dalam Hukum Positif di Indonesia.

Pengaturan peredaran dan penggunaan E-Liquid pada rokok elektrik belum di atur dalam hukum positif Indonesia. Hal ini ditunjukkan tidak diaturnya dalam pereturan Perundang-undangan, di antara lainnya: UUPK, Undang-undang Nomor 36 Tahun 2009 tentang Kesehatan, Peraturan Pemerintah Republik Indonesia Nomor 109 Tahun 2012 tentang Pengamanan Bahan yang Mengandung Zat Adiktif berupa Produk Tembakau bagi Kesehatan, Peraturan Kementrian Perdagangan Nomor 86 Tahun 2017 tentang Impor Rokok Elektrik, dan Peraturan Mentri Keuangan Nomor 146/PMK.010/2017 tentang Tarif Cukai hasil Tembakau.

\section{B. Kesimpulan Terhadap Bentuk Pengawasan Terhadap Peredaran dan Penggunaan E-Liquid dalam Rokok Elektrik yang ada di Indonesia.}

Pengawasan terhadap peredaran dan penggunaan E-Liquid dalam rokok elektrik yang ada di Indonesia belum diatur kerana di dalam Peraturan Pemerintah Nomor 109 Tahun 2012 tentang Pengawasan Bahan yang mengandung Zat Adiktif berupa Produk Tembakau bagi Kesehatan, khususnya pada Pasal 59 ini hanya mengatyr tentang pengawasan zat adiktif dari produkproduk hasil olahan tembakau. Pemerintah bersama-sama dengan Kementrian terkait, BPOM, dan Pemerintah Daerah mengawasi peredaran zat adiktif dari produk-produk hasil olahan tembakau yang beredar sesuai dengan peranan mereka masing-masing

\section{SARAN}

\section{A. Saran Terhadap Pengaturan Peredaran dan Penggunaan E-Liquid pada Rokok Elektrik dalam Hukum Positif di Indonesia.}

Pemerintah harus segera menginstruksikan BPOM untuk melakukan penelitan dan pengujian terhadap komposisi nikotin dalam E-Liquid, jika hasilnya positif, nikotin yang ada dalam E-Liquid bersumber dari Tembakau 
atau hasil olahan tembakau maka Peraturan Pemerintah Nomor 109 Tahun 2012 dapat diterapkan sebagai aturan hukum yang mengatur tentang peredaran dan penggunaan E-Liquid pada rokok elektrik, tetapi kalau hasilnya negatif Pemerintah harus membuat Aturan Hukum baru tentang zat adiktif yang terdapat dalam E-Liquid dan Aturan Hukum baru tersebut juga harus dapat menjangkau perkembangan teknologi penggunaan zat adiktif dalam bentuk apapun dimasa depan.

\section{B. Saran Terhadap Bentuk Pengawasan Terhadap Peredaran dan Penggunaan E-Liquid dalam Rokok Elektrik yang ada di Indonesia.}

Bentuk pengawasan terhadap peredaran E-Liquid adalah melakukan pengendalian E-Liquid terpadu, Kementrian Kesehatan, Kementrian Perdagangan, Kementrian Keuangan, BPOM dan Aparat Penegak Hukum, bersama-sama segera merumuskan tata cara melakukan pegendalian peredaran E-Liquid di Indonesia. Karena aturan hukum yang mengatur peredaran E-Liquid belum ada, maka pengendalian peredaran E-Liquid harus dilakukan, demi menjaga kemanan, keselamatan dan kepastian hukum bagi konsumen, karena tanpa dilakukan pengendalian, peredaran E-Liquid akan semakin meluas dan tidak terkontrol, dan dikhawatirkan E-Liquid dapat disalah gunakan oleh oknum-oknum yang tidak bertanggung jawab untuk melakukan perdagangan narkoba dengan cara menyamarkan narkoba kedalam bentuk E-Liquid.

\section{Daftar Pustaka}

A. Buku

Badan POM, Kajian Rokok Elektrik Di Indonesia, Cetakan Kedua, (Jakarta: Direktorat Pengawasan Narkotika, Psikotropika, dan Zat Adiktif, 2017) Hal. $19-23$.

Kristiyanti, Celina Tri Siwi, Hukum Perlindungan Konsumen,.Cetakan Keenam, (Jakarta: Sinar Grafika, 2017), hal.30. 
Marzuki, Peter Mahmud, Penelitian Hukum, Cetakan ke-6, (Jakarta: Kencana, 2010), hal. 136.

Marzuki, Peter Mahmud, Pengantar Ilmu Hukum, Cetakan ke-9, (Jakarta: Kencana, 2016). Hal.136.

Miru, Ahmadi dan Sutarman Yodo, Hukum Perlindungan Konsumen, Cetakan ke Sepuluh. (Jakarta: Raja Grafindo Persada, 2017), hal. 41.

Tanuwihardja, Reza Kurniawan dan Agus Dwi Susanto, 2012, Rokok Elektronik (Electronic Cigarette), J Respir Indo Vol. 32, No. 1, Januari 2012, hal. 53.

Kementrian Kesehatan Republik Indonesia, Bahaya Elektronic Cigarette, Dipublikasikan pada: Selasa, 11 Maret 2014.

B. Peraturan Perundang-Undangan

Indonesia, Undang-Undang Nomor 8 Tahun 1999 Tentang Perlidungan Konsumen, Pasal 30. , Peraturan Pemerintah Republik Indonesia Nomor 109 Tahun

2012. Peraturan Tentang Pengamanan Bahan yang Mengandung Zat Adiktif Berupa Produk Tembakau Bagi Kesehatan. (Lembaran Negara Republik Indonesia Tahun 2012 Nomor 278). Pasal 1 ayat (3 Peraturan Pemerintah Republik Indonesia Nomor 109 Tahun

2012. Peraturan Tentang Pengamanan Bahan yang Mengandung Zat Adiktif Berupa Produk Tembakau Bagi Kesehatan. (Lembaran Negara Republik Indonesia Tahun 2012 Nomor 278). Pasal 4. , Peraturan Pemerintah Republik Indonesia Nomor 109 Tahun 2012. Peraturan Tentang Pengamanan Bahan yang engandung Zat Adiktif Berupa Produk Tembakau Bagi Kesehatan. (Lembaran Negara Republik Indonesia Tahun 2012 Nomor 278). Pasal 5 ayat(1)

C. Wawancara

Tanzil, Annisa, Wawancara, dengan Amatul Syukra Tampubolon, Kepala Seksi Pengawasan Produk Tembakau dan Label Direktorat NAPZA BPOM, Kamis 19 April 2018 
, Wawancara, dengan Eva Rosita Kepala Seksi Penelitian

Yayasan Lembaga Konsumen Indonesia, Kamis 12 April 2018

D. Website

Aini, Fera Nur, Katanya Pakai Vape Ngga Berbahaya, Tapi Gadis Ini Malah

Masuk Rumah Sakit, Jadi Pikir-Pikir Lagi Deh, www.hipwee.com.

Maret 2016.

Anonim, "Inilah Efek Samping Rokok Elektrik", www.meetdoctor.com, 5 april 2016.

Aini, Fera Nur, Katanya Pakai Vape Ngga Berbahaya, Tapi Gadis Ini Malah

Masuk Rumah Sakit, Jadi Pikir-Pikir Lagi Deh, www.hipwee.com.

Maret 2016. 